DIW BERLIN

Discussion

Papers

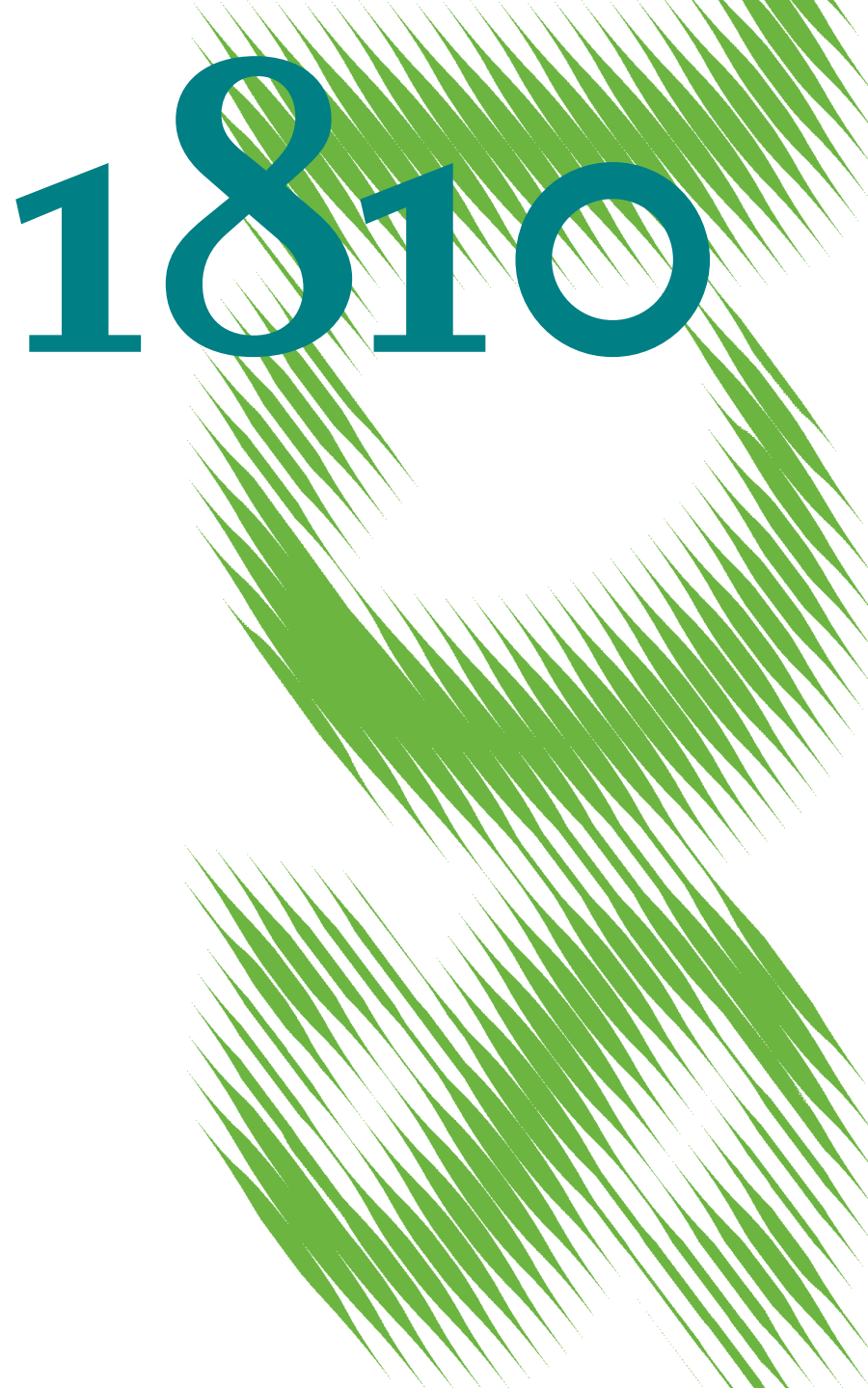

Gender Quotas in the Boardroom:

New Evidence from Germany 
Opinions expressed in this paper are those of the author(s) and do not necessarily reflect views of the institute.

IMPRESSUM

(C) DIW Berlin, 2019

DIW Berlin

German Institute for Economic Research

Mohrenstr. 58

10117 Berlin

Tel. +49 (30) $89789-0$

Fax +49 (30) $89789-200$

http://www.diw.de

ISSN electronic edition 1619-4535

Papers can be downloaded free of charge from the DIW Berlin website:

http://www.diw.de/discussionpapers

Discussion Papers of DIW Berlin are indexed in RePEc and SSRN:

http://ideas.repec.org/s/diw/diwwpp.html

http://www.ssrn.com/link/DIW-Berlin-German-Inst-Econ-Res.html 


\title{
Gender quotas in the boardroom: new evidence from Germany
}

\author{
Alexandra Fedorets ${ }^{\dagger} \quad$ Anna Gibert ${ }^{\ddagger} \quad$ Norma Burow ${ }^{\dagger}$
}

July 2019

\begin{abstract}
We examine the introduction of a gender quota law in Germany, mandating a minimum $30 \%$ of the underrepresented gender on the supervisory boards of a particular type of firms. We exploit the fact that Germany has a two-tier corporate system consisting of the affected supervisory boards and unaffected management boards within the same firm. We find a positive effect on the female share on supervisory boards of affected firms, but no effect on presidency of the board or its size. We also study whether the increased female representation has had an effect on the financial performance of the firm and conclude that, unlike some previous studies in other countries, there has not been any negative effect on the profitability of the firm, neither at the time when the law was announced nor when it was passed.
\end{abstract}

प

JEL Classification: J78, J16, M51, L25.

Keywords: Gender quota, Economics of gender, Labor discrimination, Personnel economics, Firm performance.

\footnotetext{
${ }^{\dagger}$ German Institute for Economic Research (DIW Berlin). Mohrenstraße 58, 10117 Berlin, Germany.

${ }^{\ddagger}$ Bocconi University, Statale University of Milan and DIW Berlin. Via Roentgen 1, 20136 Milan, Italy. Email corresponding author: anna.gibert@unibocconi.it.

We acknowledge the invaluable help of Franziska Bremus, Tommaso Frattini, Marcel Fratzscher, Elke Holst, Agata Maida and Katharina Wrohlich. We also thank Espen Eckbo, Daniel Ferreira and the other participants at the conference "Board diversity quotas" at Stockholm University for their comments. Last, but not least, we thank Irakli Sauer and Mansi Wadhwa for their assistance.
} 


\section{Introduction}

In this paper, we study the firm level effects of the introduction of a gender quota on supervisory boards. Starting in January 2016, German law mandates a minimum 30 percent representation of each gender on supervisory boards of large private corporations that are both listed and subject to full co-determination 11 Since the share of women sitting on boards of German corporations is historically low, this law introduced a de facto legally binding and enforceable female quota. Prior to the quota, less than 20 percent of board positions were held by women (Holst and Wrohlich, 2018). Justice Minister Heiko Maas defined the effective contribution of the quota as, "historic [...] the greatest contribution to gender equality since women got the vote" in 1918 (Smale and Miller, 2015). Quotas, some argue, are the first step in the direction of advancing the case for women in all spheres of business and public life. Increased female representation in the upper echelons of firms not only promotes more opportunities for other women today but it also provides role models for future generations (Beaman et al., 2009).

This rosy view is not unanimously shared: the conservative party and representatives of the business associations in Germany argued that positive discrimination may disadvantage the most qualified person for the job. Indeed, if the scarce female representation in leading roles is due to the women's unwillingness to perform such roles or to the lack of sufficiently prepared candidates, then positive discrimination measures may be inefficient. This ongoing controversy about quotas makes it essential to study the instances in which gender quotas have been used.

Germany was not the first European country to address the issue of female underrepresentation on boardrooms with quotas. Norway lead the way in 2003, requiring at least 40 percent of public limited company board members to be women. Many other countries, including France, Spain and the Netherlands, have since introduced gender quotas, although, in some cases, quotas are not legally binding. In this respect, the reform setup for supervisory boards in Germany, where quotas are mandatory and subject to sanctions, is similar to the Norwegian case, where quotas are mandatory. At the same time, Germany has a

\footnotetext{
${ }^{1}$ We describe the institutional background in detail in section 2
} 
unique institutional feature of a two-tier corporate system, consisting of supervisory and management boards, the latter being unaffected by the mandatory quotas. The possibility to compare the outcomes of the two boards, within a single firm, gives us a stronger setting to determine the causal effects of a gender quota on the composition of the board and to have a say on the compulsory nature of the measure compared to previous studies.

As the first to introduce a quota, the Norwegian case has attracted more attention from researchers, thusly it largely shapes the views we hold. An influential paper by Ahern and Dittmar (2012) shows a large negative effect of the Norwegian gender quota on firm value: looking at listed companies (around 500 firms), they estimate a 3.5 percent lower stock return for the affected firms for the dates around the announcement and 12.4 percent decline in Tobins $\mathrm{Q}$ in the following years, for a 10 percentage point increase of women. Matsa and Miller (2013) conduct a similar analysis, focusing on the year that the gender quota was introduced (2006), rather than the moment when the measure was approved (2003), finding more modest results: in a sample of 104 listed companies they find that the ratio of operating profits to assets was lower (by about 4 percentage points) in the affected firms relative to firms that were unaffected by the law. A later work by Eckbo et al. (2016) replicates those studies changing the date of the event and the sample selection, finding that none of the previous finding are robust.

We find that the introduction of the mandatory gender quota in Germany had the intended effect, increasing the proportion of female seats on supervisory board of affected firms by more than $10 \%$ with respect to the management boards and the unaffected firms. At the same time, the reform does not affect size of supervisory boards nor does it increase the probability of women to become an elected chairperson. We also find that the change in gender composition of supervisory boards is, to a minor extent, driven by the so-called 'golden skirts' effect, meaning that same women start holding more seats on different boards as a result of the quota introduction. Unlike the Norwegian studies, we do not find a negative effect of the quota on firm profitability, as measured by the log of earnings before interest, taxes, depreciation and amortization (EBITDA), return on equity, return on assets, and the log of wages and salaries, neither when the reform was announced (2013) nor when it was implemented (2015). 
Several studies analyze the introduction of a quota in countries other than Norway: Tyrefors and Jansson (2017) explore the consequences of the threat of a quota in Sweden while Ferrari et al. (2018) and Maida and Weber (2019) look at a temporary gender quota for Italian boardrooms of listed companies. Both a failed quota announcement and a temporary quota are different experiment setups than a permanent mandatory quota, which is the main focus of this paper. To the best of our knowledge, Bozhinov et al. (2018) is the only paper empirically studying the German quota. They focus exclusively on the role of women on the boards of affected firms, finding that women are less likely to obtain membership on important board committees than before the quota introduction.

Beyond the scope of determining the economic consequences of a gender quota, the paper also contributes to the more general understanding of how the presence of women on boards propagates its effects within firms Adams and Ferreira, 2009; Ferreira and Kirchmaier, 2013, Pathan and Faff, 2013; Bertrand et al., 2018).

The rest of the paper is organized as follows: details of the reform that took place in Germany are presented in section 2, Section 3 describes the data and the empirical strategy, while section 4 analyzes the effects of the quota on the composition of the boards. Section 5 explores the economic consequences for the firm. Robustness checks are presented in section 6. Finally, section 7 concludes.

\section{Institutional background}

For a long time, Germany has been pursuing the objective of greater diversity, especially gender diversity $\left.\right|^{2}$ In 2011, after ten years of voluntary measures failing to promote a true advancement of women, Labor Minister Ursula von der Leyen announced she had plans for a rigid legal gender quota for leading positions in the private sector (Dettmer and Pfister, 2011). However, within the same government, Family Minister Kristina Schröder favored a weaker "flexi-quota," which amounted to companies setting voluntary targets for themselves. The case was settled when Chancellor Angela Merkel, the party leader, sided with the Family

\footnotetext{
${ }^{2}$ Diversity in the election of the management board, the executive staff, and in the composition of the supervisory board is enshrined in the German corporate governance code since 2002 (Burow et al., 2018).
} 
Minister stating that she preferred a "flexi-quota," partly in the interest of harmony with their coalition partners, the liberal party FDP ('Battle with Brussels', 2013). Merkel went on to oppose the attempt by the European Union to impose a Europe-wide gender quota for the supervisory boards of stock market-listed companies, arguing that such laws should be passed by the national parliaments and, in April 2013, the conservative ruling coalition formed by her party, the CDU, its Bavarian counterpart, the CSU, and the FDP blocked a proposal by the opposition in the Bundestag to pass a minimum female board representation ('Battle with Brussels', 2013).

In September 2013, Germany held a federal parliamentary election. The CDU/CSU coalition won with an ample margin, only five seats away from the absolute majority. However, the FDP, their junior coalition partner strongly opposing the quota, fell short of meeting the $5 \%$ vote threshold, denying them seats in the Bundestag for the first time in their history. This result was completely unanticipated by the pre-election polls. As a result, the $\mathrm{CDU} / \mathrm{CSU}$ and the Social Democrats (SPD) formed a new governing "Grand Coalition" that was favorable to the introduction of the quota. We view the unanticipated election results as an unexpected shock that changed the entrenched status-quo and enabled the enactment of a gender quota. Conversely, prior to 2013, the FDP and Chancellor Merkel's own resistance to the quota, along with the reluctance of business organizations to change their conduct, made it difficult to believe that the quota was a credible threat.

In March 2015, the Law on Equal Participation of Women and Men in Leadership Positions in the Private and Public Sector ${ }^{3}$ entered into force. It gave companies a deadline until January 1, 2016 to comply with the quota.

Although the mandatory nature of the German gender quota makes it highly comparable to the Norwegian case, there are three distinct institutional elements in Germany that are crucial for the implementation and the consequences of a quota. Two relate to the particular corporate governance structure in the German tradition (the two-tier board system and the co-determination regime) and the last is a key feature of the design of the gender quota law, namely, the existence of sanctions for non-compliance.

\footnotetext{
${ }^{3}$ Gesetz für die gleichberechtigte Teilhabe von Frauen und Männern an Führungspositionen in der Privatwirtschaft und im öffentlichen Dienst of April 30, 2015 (Bundesgesetzblatt Jahrgang 2015 Teil I Nr. 17 S. 642).
} 
The corporate structure in Germany is regulated by the Stock Corporation Act $4^{4}$ It establishes a mandatory two-tier structure with a management board (Vorstand), which serves the executive duties in the firm, and a supervisory board (Aufsichtsrat), which holds the functions of control and monitoring. The management board deals with the day-today objectives of the firm, whereas supervisory board acts as a check-and-balance of the first board and appoints its members, alongside setting long-term goals and integrating the voices of other firm stakeholders (like employees, lobbies, etc.). Moreover, the Codetermination Act $5^{5}$ requires that half of the appointees of the supervisory board are employee representatives in all companies with more than 2000 employees (1000 employees for the coal and steel industry companies). Workers have the same weight in the supervisory board as shareholder representatives, except for the tie-breaking vote of the chairman, who must be appointed by the shareholders. That is why this system is sometimes called parity codetermination or full parity, as opposed to one third co-determination, which is in place for companies with 500 to 2000 employees. The distinction between the capital side and the employee side of the board simply establishes whether a member has been proposed and elected by the employees or by the shareholders of the firm, but it does not make any difference regarding their functional role and voting rights.

According to the gender quota law, all listed companies with full co-determination shall adopt: i) a mandatory $30 \%$ quota of the underrepresented gender on supervisory boards (Aufsichtsrat) or administrative boards (Verwaltungsrat); and ii) voluntary quotas individually determined by each company for the members of its executive or management board (Vorstand). A mandatory quota means that there are sanctions for non-compliance. Noncompliant elections results are automatically declared void. The seats will remain vacant until new elections are held or a member is appointed by the court $5^{6}$ Additionally, failure to meet the quota constitutes an administrative offence that can be punished with up to a $€ 50,000$ fine. Sanctions are enforced: Villeroy \& Boch, a ceramics manufacturer, was forced to leave a position on its supervisory board vacant for several months in 2018 Anger,

\footnotetext{
${ }^{4}$ Aktiengesetz of September 6, 1965 (Bundesgesetzblatt I S. 1089).

${ }^{5}$ Gesetz über die Mitbestimmung der Arbeithnehmer of May 4th, 1976 (Bundesgesetzblatt I S.1153).

${ }^{6}$ Even if vacant seats are not an obstacle to the functioning of the board, as long as there is a quorum, it could imbalance the voting power between the employer and the employee sides of the board.
} 
2018). In Norway, on the contrary, the law did not contemplate strong sanctions until it was amended two years after its passing to include the threat of dissolution of non-compliant companies (Storvik and Teigen, 2010).

The design of the German law allows us to compare directly the composition of the supervisory board, where compliance is mandatory, with that of the management board, where it is voluntary. This legal feature is useful in order to distinguish the impact of the quota from other confounding effects at the firm level. Whenever a reform to the legal framework is introduced, there is a concern with identification because firms fall into the categories of either affected by the law or not affected by the law. Determining the appropriate counterfactual becomes an issue. In order to compare the two groups, we must assume that the firms are affected by the quota in a quasi-random way. That is, that the characteristics that made them affected are not correlated to the outcomes we seek to attribute to the reform. We discuss whether this assumption is reasonable in this case in the next paragraph. However, the German two-tier board structure provides a unique identification strategy: we can measure the effect of the quota on the share of women on each type of board within the same firm.

Finally, the major issue in the Norwegian case is that boards of all public limited companies, inter-municipal, and state-owned enterprises were simultaneously affected by the quota law. This included all listed firms. It is difficult, as we mentioned before, to find a control group; with the so-far existing literature Ahern and Dittmar, 2012; Matsa and Miller, 2013; Eckbo et al., 2016; Bertrand et al., 2018) using either non-listed Norwegian firms or listed firms from other Scandinavian countries. In comparison, the German law affects listed companies only if they are subject to full co-determination. This allows us to use subsamples of the data set as the control group. These are firms that are more similar to those of the group of affected companies because they share at least one of the two characteristics that made them subject to the law; that is, they are either listed but not subject to full codetermination or not listed but subject to full co-determination. That said, we acknowledge that this is also not a perfect control group. To the extent that the largest most important German companies are usually listed and have a large number of employees, thus subject to full co-determination, they may still be different than the rest. 


\section{$3 \quad$ Empirical strategy}

\subsection{Data}

For the analysis, we employ the propriety database 'Die Großen 500' (The Largest 500) 7 which includes annual information for the 1,010 largest German firms, of which $7.71 \%$ are banks, $8.62 \%$ are insurance companies, and the rest are non-financial firms. Specifically, the database provides data on directors, both entering the supervisory and the management board. We focus on the years from 2008 to 2016, thus ensuring we have a sufficiently long prereform period to study the common trend and potential anticipation of the reform. Under the gender quota law, around 100 companies are affected, that is, they are listed and are subject to full co-determination. We have 77 in our database and more than eight times that many firms that are not affected by the quota. The total number of firms per year can be seen in table 1. The sample of firms is spread across various industries and regions $\square^{8}$ such that the effect is unlikely to be driven by a specific sector nor it is confined to a specific region.

[Table 1 about here]

Importantly the database contains information about the composition of the board, namely the names of all the members who belong either to the management board or the supervisory board with an indication of who the chairperson is. Moreover, among the members of the supervisory board, it distinguishes whether they are affiliated to the capital side (Kapitalseite) or the employee side (Arbeitnehmerseite) of the board.

\footnotetext{
7‘Die Großen 500' database ("Die Großen 500. Deutschlands Top-Unternehmen mit Anschriften, Management und Geschäftszahlen", Muessig-Verlags, 2016) comes from a German provider that hand-collects the information based on public records, mainly the annual reports of the companies.

${ }^{8}$ The distribution of industries in the sample is: automobile industries (1.31\%), chemical companies (4.70\%), sale and purchase associations (1.29), food and beverage companies(1.73\%), pharmaceutical companies $(1.38 \%)$, steel industries $(1.31 \%)$, services sector $(2.43 \%)$, power supply companies $(4.94 \%)$, whole and retail food trade $(1.02 \%)$, trade $(1.39 \%)$, holding $(3.61 \%)$, car import $(1.20 \%)$, car equipment industries $(2.45 \%)$, mechanical engineering $(4.68 \%)$, media (1.46\%), mineral oil industry $(1.08 \%)$ and retail trade (1.44\%). Regarding the regions distribution, North Rhine-Westphalia is home to the largest number of firms in the data set, amounting to a total of $29.84 \%$ of the total firms. Bavaria and Hesse had $15.9 \%$ and $15 \%$ firms, respectively, followed by Baden-Württemberg, which had the fourth largest number of firms at $13.03 \%$. All the other regions combined amount to $26.23 \%$.
} 
As seen in table 2, the sample average board size is 7 members, with a minimum of one board seat and a maximum of 40. The average size is higher in the supervisory board (9 members) than the management board (4 members). Women hold a minority of the board seats: an average of 0.18 members of the management board are female and up to 1.6 members in the supervisory board. There are more than $45 \%$ of firms without any women on their supervisory boards and more than $80 \%$ without any women on their management board.

\section{[Table 2 about here]}

In out database, board members are classified by gender, based on their first name. We listed all names of the board members and ran a script assigning them manually to the categories 'male' or 'female' whenever there was no ambiguity regarding their gender. If this classification was not possible on the base of the first name alone (for instance, if the first name was foreign or is indistinctive for males or females), we performed a search for the name and surname on the Internet, looking for public records, journal articles, or other business data sources where the person was referenced. Then, we assigned the gender according to the visual inspection of a picture or the personal pronouns used to refer to the person or their job title $?^{9}$

We complemented the database with financial data from Datastream and Compustat Global by matching the company name. This merger produced a reduced sample of about one-fourth of the original database (237 distinct firms) from 2008 to 2017. Summary statistics of the main variables are shown in Table 3 .

[Table 3 about here]

\footnotetext{
${ }^{9}$ Since most documents were in German, we were able to use the gender difference in the termination of the job titles that is frequent in the German language. For instance, a male CEO would be referred to as 'Vorsitzender' whereas a female CEO would be 'Vorsitzende.'
} 


\section{$3.2 \quad$ Empirical specification}

The intended effect of the law is to "promote equality between men and women and ... reduce structural discrimination" against women (article 1.(1).2) of the Law on Equal Participation of Women and Men in Leadership Positions in the Private and Public Sector). By explicitly addressing the proportion of women sitting on supervisory boards, we presume that the lawmakers seek, first and foremost, to balance gender representation on the supervisory board, to promote females to the highest ranks of the firms, and, additionally, to foster better opportunities for women candidates to board membership. Thus, in the first part of the analysis, we focus on the effects of the quota to achieve the aforementioned objectives by looking at the composition of the board. Using a triple differences set-up, we estimate the following specification by OLS with robust standard errors:

$$
\begin{array}{r}
Y_{b, i, t}=\alpha+\beta_{1} \text { Affected }_{i}+\beta_{2}{\text { Post }-2013_{t}+\beta_{3} \text { Board }_{b}+} \\
\beta_{4} \text { Affected }_{i} \times{\text { Post- } 2013_{t}}_{t}+\beta_{5} \text { Affected }_{i} \times \text { Board }_{b}+\beta_{6} \text { Post-2013 }_{t} \times \text { Board }_{b}+ \\
+\beta_{7} \text { Affected }_{i} \times \text { Post }_{2013_{t}} \times \text { Board }_{b}+\theta_{i}+\tau_{t}+u_{i, t},
\end{array}
$$

where $Y_{i, t}$ are several outcomes measuring the composition of the board, Affected ${ }_{i}$ is a dummy variable that takes value 1 if the firm is affected by the gender quota law and 0 otherwise, Post- $2013_{t}$ is a dummy variable that takes value 1 in the post-treatment years and 0 in the pre-treatment years, and Board $_{b}$ a dummy variable that takes value 1 for the supervisory board and 0 for the management board. The specification includes year, board, and firm fixed effects.

As we stated before, the German law makes gender quotas mandatory only for the supervisory board, whereas the management board remains unaffected. Having both a treated and an untreated board in the affected firms allows a more robust approach to identifying the effect of the quota than the most common approach of differences-in-differences. In particular, we use a different treatment and control group (supervisory board versus management board) within the treatment state (affected companies). This way we take into account firm-specific trends that influence gender compositions of both boards.

The treatment group consists of affected firms based on the list by the "Managerinnen- 
Barometer' of DIW Berlin, ${ }^{10}$ which classifies the firms according to the two criteria required by the law. We also cross-checked this list with the one produced by the Hans-BöcklerStiftung, a foundation that undertakes research in the areas of business and administration in Germany. The control group in the baseline specification contains all the other firms in the sample that are not affected: that is, the remaining large German firms that are not subject to the gender quota. 11 As we explained before, we consider the treatment year to be 2013. We believe there are no anticipatory effects going back beyond 2013, when the unexpected exit from parliament of the historic junior coalition partner of the winning party forced a change in the governing coalition and prompted a reversal in the political consensus about the gender quota.

The triple differences estimator $\hat{\delta}_{7}$ in equation (3.1) is:

$$
\begin{aligned}
\hat{\delta}_{7} & =\left(\bar{Y}_{\text {Affected,AR,Post }}-\bar{Y}_{\text {Affected,AR,Pre }}\right) \\
& -\left(\bar{Y}_{\text {Non-affected,AR,Post }}-\bar{Y}_{\text {Non-affected,AR,Pre }}\right) \\
- & \left(\bar{Y}_{\text {Affected,VST,Post }}-\bar{Y}_{\text {Affected,VST,Pre }}\right)
\end{aligned}
$$

that is, the difference in the share of females on the supervisory board (AR) of eligible firms before (Pre) and after (Post) the reform, netting out the effects of the change in means for the supervisory board of non-affected firms and the effect of the change in means for the management board (VST) of affected firms. This specification deals with the possibility that affected and non-affected firms are subject to systematically different changes besides the gender-quota reform.

Clearly, this triple differences approach is only possible when we evaluate the effect of the quota on the composition of the boards; which may be different for the supervisory and the management boards of the same company. The effect of the quota on the financial performance of the firm may not be evaluated separately for each board. In the second part

\footnotetext{
${ }^{10}$ We thank Elke Holst, Gender Studies Research Director at DIW Berlin, for sharing this information with us.

${ }^{11}$ In the second part of the analysis, we use two alternative control groups of firms that are 'almost affected' by law. Since we are using a triple differences approach, at this point, we prefer not to restrict our control group and let the complete set of fixed effects (time, firm and board fixed effects) deal with potential unobserved heterogeneity.
} 
of the analysis, we study how the increased presence of women affected the firm performance using a difference-in-difference specification as in equation (3.2).

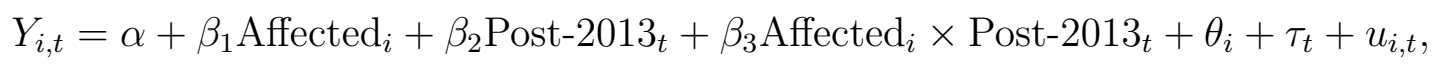

where $Y_{i, t}$ are firm-level financial variables and the treatment is defined as before: firms that fulfill the criteria of the law times a dummy for the year 2013 and after. The control group in this part of the analysis are firms that share one of the two requirements of the law with the treated firms. That way, we ensure that they are more similar to the treated group in one of the two relevant dimensions at a time. The hypothesis is that the composition of the supervisory board in absence of the quota may have been optimally configured; thus, any

interference may be potentially detrimental to the profitability of the firm. Moreover, Matsa and Miller (2013) argue that females have a different leadership style that may be reflected in their personnel decisions, which in turn may also have an effect on the economic outcomes of the firm.

\section{Effect of the quota on board composition}

Figure 1 plots the share of women in affected (solid line) versus non-affected (dotted line) firms. The increase in the difference in the average share of women across firm groups is the largest on the supervisory board, as opposed to the management board, where the difference is not noticeable for affected and non-affected firms. Further, the rate of growth in the supervisory board is larger for the affected firms than for the non-affected ones. From the graph, however, it is not clear whether this effect is driven by the introduction of the law or it is an exacerbation of a secular trend.

[Figure 1 about here]

In order to investigate the causal effect of the quota on the share of women on the supervisory board, we estimate equation (3.1) using triple differences (DDD). Results are 
shown in table 4. The share of women increases over time and female representation is higher in the supervisory board than in the management board for affected as well as non-affected firms. The group of affected firms does not have more women on the board in general. The DDD estimator is positive and significant. The effect of the reform can be quantified as half an additional woman. The mean increase in female representation on the supervisory board of eligible firms is $9.3 \%$ higher than on the management board of the same firms.

[Table 4 about here]

Besides its direct effect on the share of female board members, a gender quota may have other effects on the composition of the board. Note that the law imposes a percentage of women, but it remains silent as to which seats these women have to fill. Firms may choose to comply with the quota by creating additional board seats and filling them with women. In this case, we should observe an increase in the size of the board of affected companies driven by the desire to satisfy the law and not due to organizational needs. In column (1) of table 5, we find no significant effect of the quota on board sizes. There is no evidence that boards subject to the quota increased their average number of members after the reform when compared to those boards not subject to the quota in the same firms and in non-affected firms.

We now turn to the effect of the introduction of the quota on the probability that the person chosen to be president of the board is female. An increase in the number of female members on the board may imply that they have a greater chance of being elected chairperson of such board. As seen in column (2) of table 5, the coefficient of the DDD estimator is very small and insignificant: this suggests that women were not more likely to become elected chairperson of the board.

Where do these female board members come from? First, we are interested to see whether newly appointed women become board members for the first time or they are already sitting on supervisory or management boards of other companies in our sample. The phenomenon, known as the 'golden skirts,' consists of increasing female board participation by concentrating a larger number of board memberships in the hands of a few women. Consequently, those 
women accumulating more positions are highly demanded and the pay gap at the top of the firm is possibly reduced but the quota does not serve the greater objective of increasing promotions and pay for women at the lower levels of the corporate hierarchy. Some evidence of this is found by Bertrand et al. (2018) for Norway. To test for the 'golden skirts' hypothesis, we construct an index of the number of mandates for female and male board members in every firm for each year. Whenever a person sits in more than one board simultaneously, we call it a multiple mandate. The variable 'Female mandates ratio' is defined as the number of multiple mandates for females divided by the number of multiple mandates for males, and it varies across firms and over time. A ratio higher than 1 means that women are sitting on more boards simultaneously than men. The effects after the reform can be found in column (3) of table 5. We do find a very small positive effect in the ratio of female to male multiple mandates, which seems to indicate that part of the increase in female representation benefits women who were already serving on boards instead of increasing the participation of new women (Bozhinov et al., 2018).

\section{[Table 5 about here]}

As shown in table 3, female participation is almost twice as high on the employee side of supervisory boards compared to the capital side. Therefore, in the next step, we analyze the effect of the quota separately on employee side versus capital side of the supervisory board. Table 6 shows that the effect is present on both sides of the board. Hence, firms do not seem to be filling only the employee side seats with female board members but they are also present in the capital side of the supervisory board. Moreover, the opposite is true, and the rise in the female share is higher on the capital side of firms. In total, the employee side of the supervisory board still has more female representation, around $26 \%$ in 2016, compared to $22 \%$ on the capital side.

[Table 6 about here] 
Next, we analyze the evolution of the share of women on the company boards over time, inspecting the coefficient of the leads and lags around the treatment year (2013) in table 7 . The omitted year is 2013; hence, all coefficients must be interpreted with respect to this baseline. The DDD coefficients for all years between 2008 and 2012 are insignificant. This implies that, prior to the reform, there is no evidence that the two boards were on differing trend. Conversely, after the gender quota became law in 2015, entering into force in 2016, the representation of women on the boards of affected companies increased above their 2013 levels. As seen above, the first increase in the share of female representation in affected firms occurs in 2013 (table 7). In 2015, when the quota law is approved, the share increases further and it escalates again in 2016 as the law enters into force. The delayed effects could be due to the fact that the same firms that increased the number of females on their boards before - early adopters - deepen their commitment to increasing the share of females by hiring even more women. Alternatively, it could be other firms that increased their share of women on their board - late adopters - while the early adopters stay put. In the box plot in figure 2 , we can observe a shift upwards of the whole distribution of the share of females on boards for affected companies over the years. The variance of the distribution does not shrink and our data suggest that the late adopters are different companies than the early adopters.

[Table 7 about here]

[Figure 2 about here]

Comparing the characteristics of early adopters versus late adopters, in table 8, firms that took steps earlier toward meeting the gender quota have, on average, fewer employees than late adopters. They tend to have a lower share of females on board to start with (in year 2012) but the average increase of the share is smaller compared to the increase of late adopters in 2016. Smaller firms may have greater flexibility to make changes to their supervisory boards, but they may also face a reduced pool of potential female board members to choose from. It is reasonable to expect that they would like to act before larger firms do in order to attract good candidates. 
[Table 8 about here]

\section{Effect of the quota on economic performance}

In this section, we study the effect of the gender quota on several measures of firm profitability. We estimate equation (3.2) by OLS with robust standard errors using a difference-indifference approach. The dependent variables are the log of earnings before interest, taxes, depreciation and amortization ( $\log$ EBITDA), the return on assets (ROA), return on equity (ROE), the size of the firm estimated as the log of assets, the log of the number of employees, and $\log$ wages. The financial variables are winsorized at the $1 \%$ level.

Table 9 presents the estimates of the difference-in-difference coefficient for two different control groups: the upper panel uses as a control group private firms subject to full codetermination in 2012 and the lower panel uses as a control group public firms subject to a weaker form of employee representation in 2012. Each of these groups shares with the affected firms one of the two criteria that the law establishes for being subject to the quota; the failure to meet the second requirement makes firms in the control groups 'almost affected' yet not legally bound by the quota.

The upper panel in table 9 presents the results of estimating equation (3.2) on the sample of all firms subject to full co-determination in 2012; that is, all firms with 2000 employees or more. Since firms that are both listed and subject to full co-determination are affected by the law, the control group contains firms that are private but have the same range of employee numbers. The comparison is between public (treated) and private (control) firms. Results show a strong and significant increase in the share of women on the supervisory board, whereas such drive toward increased female representation is not present on management boards. The same pattern is true for the lower panel in table 9 ; here the sample comprises all public firms with 500 employees or more. Firms with between 500 and 2000 employees are subject to a weaker form of employee representation, under the One Third Representation Act (Drittelbeteiligungsgesetzes), where one-third of the seats on the board must be reserved for employees. Hence, the comparison is between public firms with 
full co-determination (treated) and with one-third employee representation (control). The results regarding the effect of the quota on financial variables do not show a clear picture. Coefficients are insignificant or economically small except for a higher log of EBITDA using both control groups and a lower ROE only when we use the one-third representation control group.

[Table 9 about here]

In table 10, we repeat the same analysis as in table 9, this time using 2015 as the treatment period, the year when the gender quota law was actually implemented. As we saw in the previous section, and we corroborate here, the share of women on supervisory boards increased in the affected firms not only when the quota was announced, but also when it was implemented. The share of women on the management board, on the contrary, did not. The only consistent result regarding the effect of the quota on economic performance is a mildly positive log of EBITDA.

[Table 10 about here]

Next, we focus on the intensive margin of adjustment to the quota law. In table 11, we exploit the regulation of the Co-determination Act that determines the size of the board for different firms. Firms with between 2,000 and 10,000 employees must have 12 seats on the board; between 10,000 and 20,000 they must have 16 seats; and for more than 20,000 employees 20 seats. Larger boards require incorporating a larger number of women in order to fulfill the $30 \%$ threshold. According to this strategy, the more women a company is forced to integrate, the more intensely the effects of the reform will show. Looking only at affected firms, we take this distance to compliance as an exogenous distribution about the effort companies need to make in order to comply with the quota. This is an approach similar to Ahern and Dittmar (2012), where they compute the distance from the pre-treatment share of female representation to the quota. As we see in table 11, there is no significant increase in the number of female board members on any board nor an effect on the financial variables. 
[Table 11 about here]

We discuss briefly whether the positive effect in EBITDA that we find above is concentrated in a geographical area. We compute the share of women on the supervisory board at the regional leve ${ }^{12}$ before the reform. A higher number means that the percentage of women sitting on the supervisory boards of that region in 2012 was, on average, larger than in a different region. As seen in table 12, the log of EBITDA is insignificant, except for the fourth quantile, where it is large and positive. These are the firms in the region where the share of women on board was highest from the onset. One explanation may be that firms are not randomly assigned to a region and, thus, more progressive regions may have a better attitude toward hiring women and are better able to extract their talent. Another explanation is that firms in the fourth quantile region needed to incorporate fewer women on average when the law passed. This explanation implies that a lower increase in female participation raises earnings above their peers level. However, this conclusion is not trivial since we do not know the average size of the board in each quantile: ceteris paribus, hiring an additional women for a smaller boards increases the share of women more than in larger boards. In table 12 we specify the effect of the reform on the number of women in each board for all quantiles. The increase in the number of women in the supervisory board is the smallest in the fourth quantile. However, if we consider changes in the management board as well, there is no clear association between the number of women entering all boards and the EBITDA of the firm.

[Table 12 about here]

Lastly, a comment on the plausibility of the result that an increase in the proportion of women on the board does not have a negative effect on firm profitability. Earlier works on the Norwegian law find a large negative effect of the quota, claiming that women have a different leadership style (Matsa and Miller, 2013) - possibly, less effective - to explain

\footnotetext{
${ }^{12}$ We differentiate between Bundesländer, being the NUTS-1 level of regional disaggregation.
} 
their results. Moreover, Ahern and Dittmar (2012) find evidence that the stock market penalized companies that were affected by the quota, the implication being that shareholders anticipated a negative impact of the quota on results. Other works find insignificant results (Smith, 2014), as we do here, but an absence of significance does not necessarily mean the effect of the quota on profitability is zero. We bring direct evidence on the perception of firm stakeholders regarding the imminent introduction of a gender quota in tables 9 and 10 . As it appears that firms did not attempt to compensate for the mandatory increase in the share of women on their supervisory board by reducing the number of women on their management board, we can infer that the perception of the quota was not negative. We are able to observe an action that reveals the expectation of the stakeholders about the future effect of the quota more directly than the stock prices. As seen above, we do not find any negative effects of the introduction of the quota on any of the profitability measures taken into consideration (return on assets, return on equity and operating profits), which seems to corroborate the stakeholders expectations.

\section{Robustness analysis}

Placebo test for eligibility. We look at the same baseline regression as in (3.2) but using as a definition of affected firms a subset of the sample randomly selected. As expected, we find no effect for the placebo group of treated firms in the results in appendix A. The effect of time on the increase of women across all boards - as reflected in the coefficient of the dummy for the year 2013 - is consistent with the previous results.

Regional time trends. In the differences-in-differences specification, we assume that, in the absence of the treatment, the average outcome in the treated and the control group would have followed their pre-treatment trend. In order to weaken the assumption of parallel trends, we allow the time trend to change in different regions by adding time and region interaction terms:

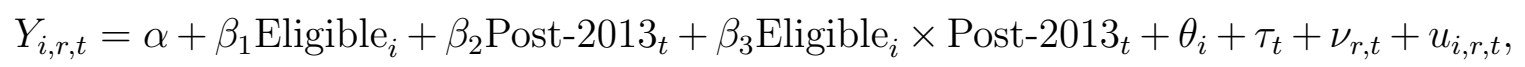


where the subindex $r$ indicates regional variation at the NUTS-1 level. In the case of equation (6.1), the treated and control groups are still assumed to have a common trend but this trend is allowed to vary from region to region. Results in appendix $B$ are significant for the supervisory board and they are not for the management board, as it has been the case throughout all specifications, and the magnitude of the coefficients is very similar.

Alternative control groups. In section 5, we use companies with one of the two characteristics of eligibility under the quota law as the control group; that is, they are subject to full co-determination but not listed or listed but subject to a weaker form of employee representation. As a further robustness check, we look at a reduced control group using propensity score matching to select the non-affected firms that are closest to the affected firms from the point of view of the pre-treatment characteristics. This process takes place in two steps. First, we estimate a probit regression of the affectedness on the several characteristics of the firm: log EBITDA, ROE, ROA, size, log of employees, log wages, as well as their first, second, third, and fourth differences to capture firms that are on a similar pre-reform trend. Then we select the 'closest neighbors' for each treated firm as predicted by the probit regression. Our implementation of propensity score matching uses matched firms as controls weighted by their relative closeness to the treated units. Appendix C shows the comparison of the variables for the matched and unmatched samples, with the results of the estimation found in appendix $\mathrm{D}$. The increase in the share of women in the supervisory board is even larger than what we find in our baseline specification. The log EBITDA becomes larger and is very significant and we also conclude that firms grow both in size and in number of employees.

\section{Conclusion}

We study the introduction of a mandatory gender quota on the supervisory board of Germany's two-tier corporate system. The law affected listed companies that were subject to the full co-determination regime of employee representation. It also considers the voluntary targets by the companies themselves regarding the management board of the company and by the rest of companies that were not specifically targeted by the law. This feature of 
the German quota law provides us a special insight into a relevant policy question: how do mandated quotas perform relative to voluntary quotas to achieve the policymakers purported goal of "gender balance in the boardroom"? We are able to exploit the variation in treatment across boards within the same firm, created exogenously by the law, and across firms that are affected, or not, by the regulation. We find a significant effect of the quota on the share of women on the supervisory board of about $10 \%$ percentage points (which, on average, means slightly more than one additional woman). On the contrary, there is no effect in the proportion of women serving on the management board, where all companies were asked to define their own quota freely. Our results present clear and robust evidence that gender quotas achieve a higher female representation at the top of the company if they are mandatory. Suggestions and recommendations are less effective, although we cannot rule out that they may have an impact. This is in line with the very limited or non-existent advancement the literature finds when quotas are not accompanied by sanctions (Smith, 2014). Our second main result is that we cannot find a negative effect of the quota on the profitability of the firm when looking at the earnings before interest, taxes, amortization and depreciation (EBITDA), at return on equity, and at return on assets. In some specifications, we find a mild increase in EBITDA, especially in regions where female representation on the board was high before the reform took place.

The increase in female participation at the board appears to be financially costless. We view this evidence as consistent with the fact that companies could have compensated the mandated increase in one board by decreasing the share or the number of women in the other board in order to avoid any unforeseen negative consequences of adding women. We find no evidence of this, suggesting that they did not expect to suffer a financial loss, which is corroborated by our analysis. Whether additional costs of the quota implementation would appear in the long run, as well as what kind of benefits accrue to the firms and society are matters for future research. 


\section{References}

Adams, R. B. and Ferreira, D. Women in the Boardroom and Their Impact on Governance and Performance. Journal of Financial Economics, 94(2):291-309, 2009.

Ahern, K. and Dittmar, A. The Changing of the Boards: The Impact on Firm Valuation of Mandated Female Board Representation. Quarterly Journal of Economics, 127(1):137197, 2012.

Anger, H. Gender Quotas Make an Impact in the Boardroom. Handelsblatt Today, September 14 2018. URL https://www.handelsblatt.com/today/companies/ women-in-business-gender-quotas-make-an-impact-in-the-boardroom/23583340. html.

'Battle with Brussels'. Battle with Brussels: Germany to Lobby against EU Gender Quota. Spiegel Online, March 6 2013. URL https://www.spiegel.de/international/europe/ germany-to-lobby-against-eu-gender-quota-a-887174.html.

Beaman, L., Chattopadhyay, R., Duflo, E., Pande, R., and Topalova, P. Powerful Women: Does Exposure Reduce Bias? The Quarterly Journal of Economics, 124(4):1497-1540, November 2009.

Bertrand, M., Black, S. E., Jensen, S., and Lleras-Muney, A. Breaking the Glass Ceiling? The Fffect of Board Quotas on Female Labour Market Outcomes in Norway. The Review of Economic Studies, 86(1):191-239, 2018.

Bozhinov, V., Koch, C., and Schank, T. The Second Glass Ceiling: Womens Role in Supervisory Boards of German Firms. Schmalenbach Business Review, pages 1-27, 2018.

Burow, N., Fedorets, A., and Gibert, A. Frauenanteil in Aufsichtsräten steigt, weitere Instrumente für die Gleichstellung gefragt. DIW-Wochenbericht, 85(9):149-155, 2018.

Dettmer, M. and Pfister, R. The Quota Debate: Leading Companies Propose Voluntary Gender Targets. Spiegel Online, October 17 2011. URL https://www.spiegel.de/international/germany/ the-quota-debate-leading-companies-propose-voluntary-gender-targets-a-792204 . html.

Eckbo, B. E., Nygaard, K., and Thorburn, K. S. Board Gender-Balancing and Firm Value. European Corporate Governance Institute - Finance Working Paper, 463, 2016.

Ferrari, G., Ferraro, V., Profeta, P., and Pronzato, C. Do Board Gender Quotas Matter? Selection, Performance and Stock Market Effects. IZA Discussion Paper, 11462, 2018.

Ferreira, D. and Kirchmaier, T. Boards and Shareholders in European Listed Companies. In Belcredi, M. and Ferrarini, G., editors, The Oxford Handbook of Innovation, chapter 4, pages 191-224. Cambridge University Press, 2013. 
Holst, E. and Wrohlich, K. Women Executives Barometer 2018. DIW Weekly Report, 3, 2018.

Maida, A. and Weber, A. Female Leadership and Gender Gap within Firms: Evidence from an Italian Board Reform. IZA Discussion Paper Series, 12099, January 2019.

Matsa, D. and Miller, A. A Female Style in Corporate Leadership? Evidence from Quotas. American Economic Journal: Applied Economics, 5(3):136-169, 2013.

Pathan, S. and Faff, R. Does Board Structure in Banks Really Affect their Performance? Journal of Banking \& Finance, 37(5):1573-1589, 2013.

Smale, A. and Miller, C. Germany Sets Gender Quota in Boardrooms. The New York Times, March 6 2015. URL https://www.nytimes.com/2015/03/07/world/europe/ german-law-requires-more-women-on-corporate-boards.html.

Smith, N. Gender Quotas on Boards of Directors. IZA World of Labor, page 7, 2014.

Storvik, A. and Teigen, M. Women on Board: The Norwegian Experience. Friedrich Ebert Stiftung International Policy Analysis, 2010.

Tyrefors, B. and Jansson, J. Gender Quotas in the Board Room and Firm Performance: Evidence from a Credible Threat in Sweden. IFN Working Paper, 1165, 2017. 


\section{Figures and Tables}

Figure 1: Evolution of the share of women on supervisory boards and management boards from 2008 through 2016 by affectedness

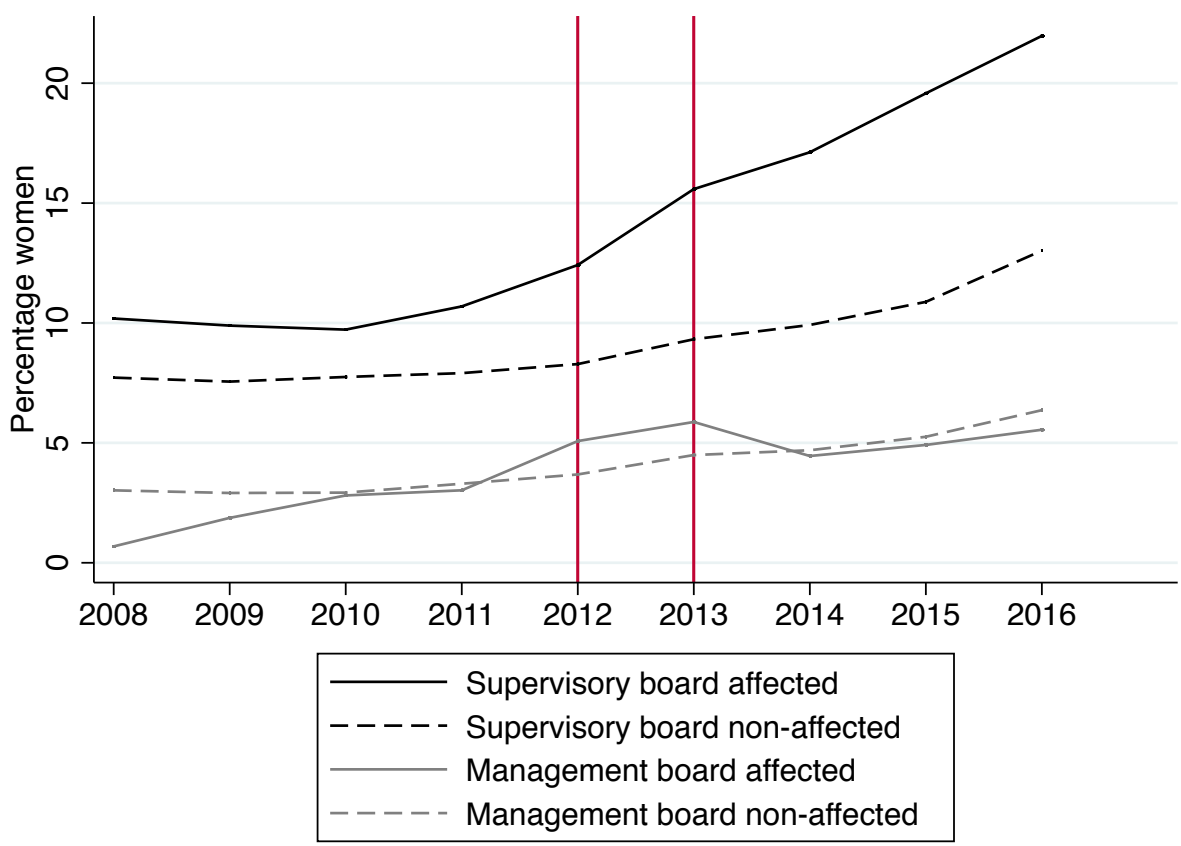

Note: An 'affected' company is defined as a company that satisfies the two criteria required by the law to fall under the obligation of implementing a gender quota: being listed on the stock exchange and being subject to the Co-determination Act. The rest are considered 'non-affected.'

Source: Muessig Verlag (2016): Die Großen 500. 
Figure 2: Distribution of the share of women on the supervisory boards of affected firms by year (whiskers box plot)

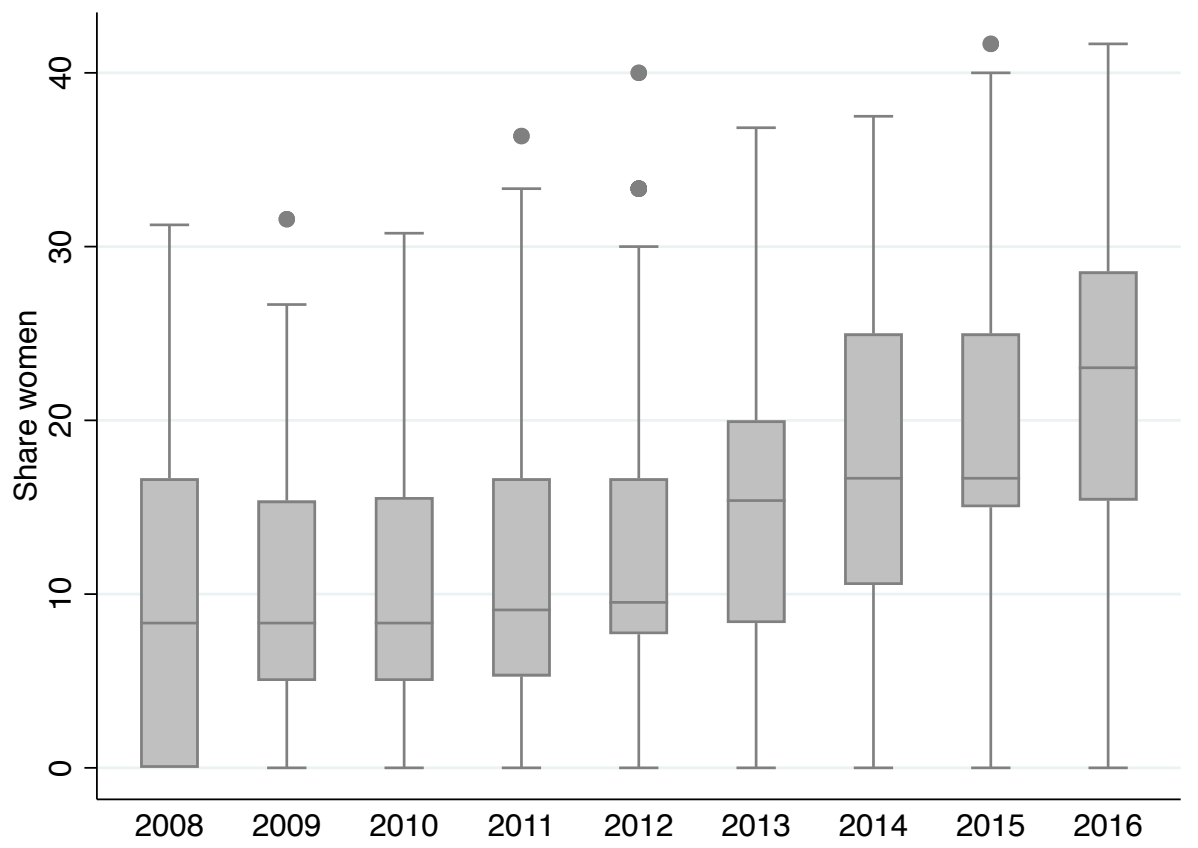

Note: An 'affected' company is defined as a company that satisfies the two criteria required by the law to fall under the obligation of implementing a gender quota: being listed on the stock exchange and being subject to the Co-determination Act.' The share of women is in percentage.

Source: Muessig Verlag (2016): Die Großen 500. 
Table 1: Number of firms per year by affectedness

\begin{tabular}{lccc} 
Staus & Non-Affected & Affected & Total \\
\hline 2008 & 805 & 66 & 871 \\
& $(92.4)$ & $(7.6)$ & $(100.0)$ \\
2009 & 823 & 70 & 893 \\
& $(92.2)$ & $(7.8)$ & $(100.0)$ \\
2010 & 842 & 73 & 915 \\
& $(92.0)$ & $(8.0)$ & $(100.0)$ \\
2011 & 855 & 72 & 927 \\
& $(92.2)$ & $(7.8)$ & $(100.0)$ \\
2012 & 856 & 73 & 929 \\
& $(92.1)$ & $(7.9)$ & $(100.0)$ \\
2013 & 752 & 73 & 825 \\
& $(91.2)$ & $(8.8)$ & $(100.0)$ \\
2014 & 742 & 76 & 818 \\
& $(90.7)$ & $(9.3)$ & $(100.0)$ \\
2015 & 739 & 77 & 816 \\
& $(90.6)$ & $(9.4)$ & $(100.0)$ \\
2016 & 621 & 77 & 698 \\
& $(89.0)$ & $(11.0)$ & $(100.0)$ \\
Total & 7035 & 657 & 7692 \\
& $(91.5)$ & $(8.5)$ & $(100.0)$
\end{tabular}

Note: An 'affected' company is defined as a company that satisfies the two criteria required by the law to fall under the obligation of implementing a gender quota: being listed on the stock exchange and being subject to the Co-determination Act. The rest are considered 'non-affected.' Percentages are in parentheses. Source: Muessig Verlag (2016): Die Großen 500. 
Table 2: Board size

\begin{tabular}{lccccc} 
& count & mean & sd & min & max \\
\hline Members management board & 7219 & 4.2 & 2.0 & 1 & 16 \\
Members supervisory board & 7674 & 8.9 & 7.0 & 0 & 40 \\
Supervisory board employee side & 4254 & 5.6 & 2.6 & 1 & 14 \\
Supervisory board capital side & 5671 & 6.7 & 3.6 & 1 & 37 \\
Female members management board & 7219 & 0.2 & 0.5 & 0 & 4 \\
Female members supervisory board & 4227 & 1.7 & 1.6 & 0 & 8 \\
Female members supervisory board employee side & 4254 & 1.1 & 1.2 & 0 & 8 \\
Female members supervisory board capital side & 5671 & 0.6 & 1.0 & 0 & 7
\end{tabular}

Note: The first column presents the number of observations, the second presents the mean value, the third presents the standard deviation, and the fourth and fifth columns present the minimum and maximum value respectively.

Source: Muessig Verlag (2016): Die Großen 500. 
Table 3: Summary statistics of the main variables

\begin{tabular}{lccccc} 
& count & mean & sd & $\min$ & $\max$ \\
\hline Log EBITDA & 1492 & 13.13 & 1.72 & 5.83 & 17.50 \\
ROA & 1157 & 3.03 & 6.33 & -39.34 & 50.80 \\
ROE & 1153 & 6.57 & 29.10 & -404.93 & 99.77 \\
Firm size & 2676 & 15.19 & 1.71 & 11.63 & 20.05 \\
Log employment & 5691 & 8.53 & 1.72 & 1.61 & 13.37 \\
Log wages & 985 & 3.35 & 1.61 & -3.27 & 5.99
\end{tabular}

Note: EBITDA are earnings before interest, taxes, depreciation and amortization, ROE is net income divided by equity, ROA net income divided by assets, firm size is the log of the total assets, employment is the number of workers in the firm, and wages per employee are wages and salaries divided by the number of employees. The first column presents the number of observations, the second presents the mean value, the third presents the standard deviation, and the fourth and fifth columns present the minimum and maximum value respectively.

Source: Muessig Verlag (2016): Die Großen 500, Datastream and Compustat Global. 
Table 4: Effect of the gender quota on the share of women on the board

\begin{tabular}{|c|c|c|c|c|}
\hline & \multicolumn{2}{|c|}{ All sample } & \multirow{3}{*}{$\begin{array}{l}\begin{array}{l}\text { Non-financial } \\
\text { firms }\end{array} \\
\frac{(3)}{\text { Share women }}\end{array}$} & \multirow{3}{*}{$\begin{array}{c}\begin{array}{c}\text { Firms } \\
\text { West Germany }\end{array} \\
(4) \\
\text { Share women }\end{array}$} \\
\hline & $(1)$ & $(2)$ & & \\
\hline & Share women & Average share & & \\
\hline \multirow[t]{2}{*}{ Time dummy } & $3.950^{* * *}$ & $2.177^{* * *}$ & $3.280^{* * *}$ & $4.038^{* * *}$ \\
\hline & $(0.425)$ & $(0.324)$ & $(0.474)$ & $(0.434)$ \\
\hline \multirow[t]{2}{*}{ Affected } & 1.295 & -0.924 & 1.160 & 1.193 \\
\hline & $(1.565)$ & $(0.937)$ & $(1.568)$ & $(1.566)$ \\
\hline \multirow[t]{2}{*}{ Supervisory board } & $4.709^{* * *}$ & $4.662^{* * *}$ & $3.742^{* * *}$ & $4.477^{* * *}$ \\
\hline & $(0.190)$ & $(0.162)$ & $(0.212)$ & $(0.192)$ \\
\hline \multirow[t]{2}{*}{ Time dummy $\times$ Affected $\times$ Supervisory board } & $4.571^{* * *}$ & $4.428^{* * *}$ & $4.670^{* * *}$ & $4.878^{* * *}$ \\
\hline & $(0.898)$ & $(0.736)$ & $(0.936)$ & $(0.909)$ \\
\hline Time FE & Yes & Yes & Yes & Yes \\
\hline Firm FE & Yes & Yes & Yes & Yes \\
\hline Observations & 13922 & 14085 & 11424 & 13034 \\
\hline R-squared & 0.47 & 0.55 & 0.47 & 0.45 \\
\hline F-statistic & 153.07 & 219.73 & 102.53 & 139.61 \\
\hline
\end{tabular}

Note: The independent variable is the annual share of female members over the total members of the board in column (1), (3), and (4), with the average share of females in all periods before and after the reform in column (2). The treatment year is 2013. Affected firms are those that satisfied the requirements of the quota law: being listed and subject to parity co-determination under the Co-determination Act. Supervisory board is a dummy variable that takes value 1 for the supervisory board and 0 for the management board. Robust standard errors in parentheses. Significance ${ }^{*} p<0.1,{ }^{* *} p<0.05,{ }^{* * *} p<0.01$.

Source: Muessig Verlag (2016): Die Großen 500. 
Table 5: Effect of the gender quota on the board size, female president and female mandates ratio

\begin{tabular}{lccc} 
& $\begin{array}{c}(1) \\
\text { Board size }\end{array}$ & $\begin{array}{c}(2) \\
\text { Female } \\
\text { president }\end{array}$ & $\begin{array}{c}(3) \\
\text { Female mandates } \\
\text { ratio }\end{array}$ \\
\hline Time dummy & 0.035 & 0.006 & $0.058^{* * *}$ \\
& $(0.155)$ & $(0.007)$ & $(0.007)$ \\
Affected & $-2.016^{* * *}$ & -0.007 & 0.031 \\
& $(0.432)$ & $(0.007)$ & $(0.026)$ \\
Supervisory board & $4.764^{* * *}$ & 0.004 & $0.036^{* * *}$ \\
& $(0.0826)$ & $(0.003)$ & $(0.003)$ \\
Time dummy $\times$ Affected $\times$ Supervisory board & 0.489 & -0.012 & $0.032^{*}$ \\
& $(0.301)$ & $(0.016)$ & $(0.013)$ \\
Time FE & Yes & Yes & Yes \\
Firm FE & & & \\
\hline Observations & Yes & Yes & Yes \\
R-squared & 14893 & 13011 & 14072 \\
F-statistic & 0.63 & 0.35 & 0.43 \\
& 691.65 & 2.48 & 72.33
\end{tabular}

Note: The independent variable is the board size measured as the number of members of the board in column (1), a dummy variable that takes value 1 if the president of the board is female and zero otherwise in column (2) and the ratio of female to male multiple board mandates in column (3). The treatment year is 2013. Affected firms are those that satisfied the requirements of the quota law: being listed and subject to parity co-determination under the Co-determination Act. Supervisory board is a dummy variable that takes value 1 for the supervisory board and 0 for the management board. Robust standard errors in parentheses. Significance ${ }^{*} p<0.1,{ }^{* *} p<0.05,{ }^{* * *} p<0.01$.

Source: Muessig Verlag (2016): Die Großen 500. 
Table 6: Effect of the gender quota on the employee side and capital side of supervisory boards

(1)

Dep. var: share women

Time dummy

Affected

Supervisory board

\begin{tabular}{ccc} 
Total & Employee side & Capital side \\
\hline $3.950^{* * *}$ & $3.740^{* * *}$ & $4.594^{* * *}$
\end{tabular}

(2)

3.987

$4.709^{* * *} \quad 14.88^{* * *}$

$3.440^{*}$

Yes

\begin{tabular}{ccc} 
Yes & Yes & Yes \\
Yes & Yes & Yes \\
\hline 13922 & 11893 & 13310 \\
0.47 & 0.55 & 0.43 \\
153.07 & 231.47 & 74.14
\end{tabular}

Note: The independent variable is the share of female members over the total members of the board and each respective side of the supervisory board. The treatment year is 2013. Affected firms are those that satisfied the requirements of the quota law: being listed and subject to parity co-determination under the Co-determination Act. Supervisory board is a dummy variable that takes value 1 for the supervisory board and 0 for the management board. Robust standard errors in parentheses. Significance ${ }^{*} p<0.1,{ }^{* *} p<0.05$, $* * * p<0.01$.

Source: Muessig Verlag (2016): Die Großen 500. 
Table 7: Effect of the gender quota on the share of women on the supervisory board over time

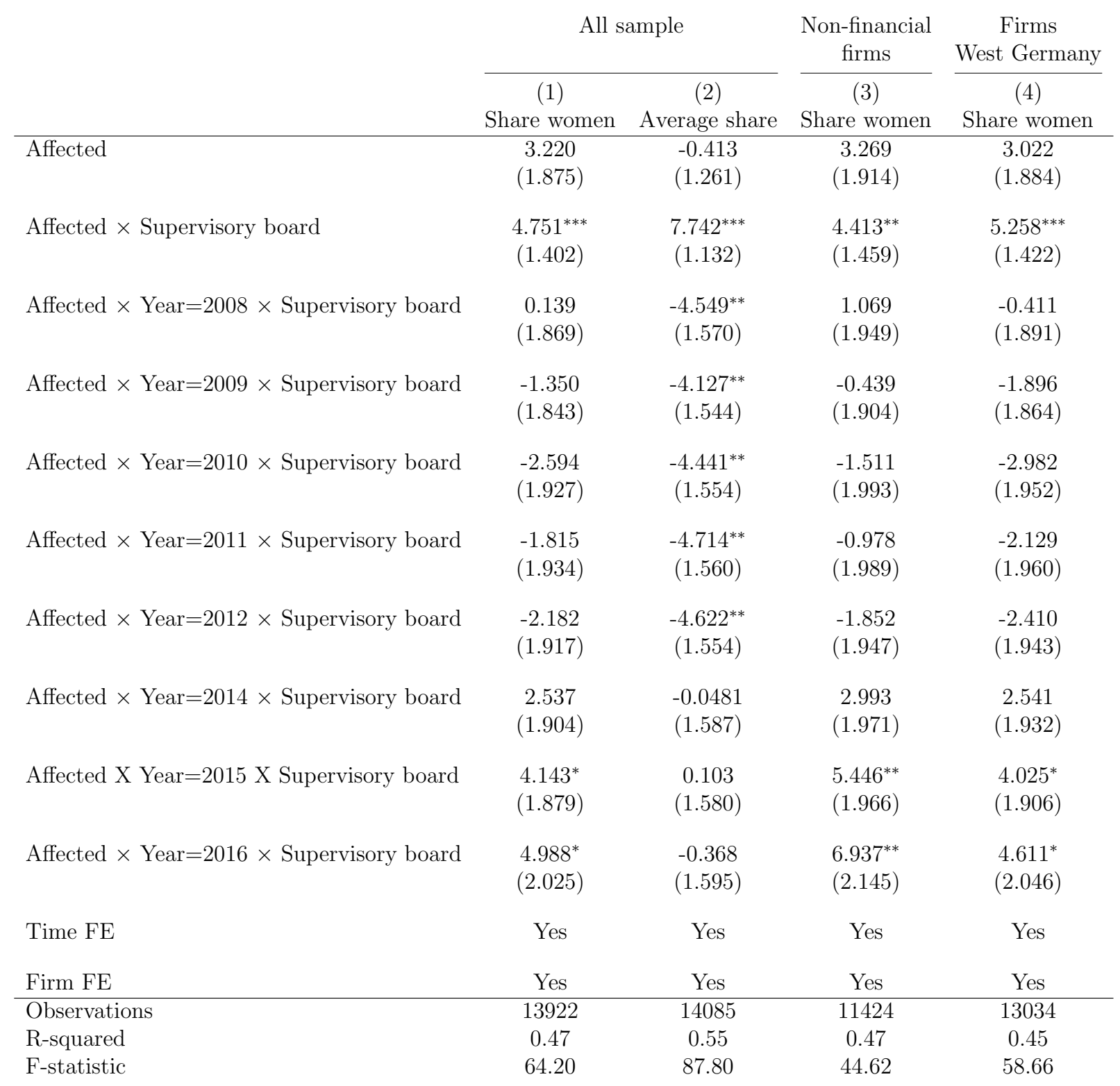

Note: The independent variable is the share of female members over the total members of the board in column (1), (3), and (4), with the average share of females in all periods before and after the reform in column (2). Affected firms are those that satisfied the requirements of the quota law: being listed and subject to parity co-determination under the Co-determination Act. Supervisory board is a dummy variable that takes value 1 for the supervisory board and 0 for the management board. Time dummies have been included for years 2008 to 2016 . The omitted year is 2013 . Robust standard errors in parentheses. Significance ${ }^{*} p<0.1{ }^{* *}$ $p<0.05,{ }^{* * *} p<0.01$.

Source: Muessig Verlag (2016): Die Großen 500. 
Table 8: Descriptive statistics of affected firms which increased the share of women on board in 2013 (early adopters) and in 2016 (late adopters).

\begin{tabular}{lccccc} 
Early adopters & & & & & \\
& count & mean & sd & min & max \\
\hline Employees & 31 & 46083.39 & 62829.99 & 1578 & 269493 \\
East Germany & 31 & 0.00 & 0.00 & 0 & 0 \\
West Germany & 31 & 1.00 & 0.00 & 1 & 1 \\
Banks & 31 & 0.10 & 0.30 & 0 & 1 \\
Non-financial firms & 31 & 0.87 & 0.34 & 0 & 1 \\
Insurance & 31 & 0.03 & 0.18 & 0 & 1 \\
Pre-share women & 30 & 10.91 & 8.21 & 0 & 30 \\
Change in share women & 30 & 8.77 & 7.89 & 1 & 33
\end{tabular}

Late adopters

\begin{tabular}{lccccc} 
& count & mean & sd & min & max \\
\hline Employees & 30 & 47568.20 & 96092.20 & 3539 & 508036 \\
East Germany & 31 & 0.03 & 0.18 & 0 & 1 \\
West Germany & 31 & 0.97 & 0.18 & 0 & 1 \\
Banks & 31 & 0.10 & 0.30 & 0 & 1 \\
Non-financial firms & 31 & 0.90 & 0.30 & 0 & 1 \\
Insurance & 31 & 0.00 & 0.00 & 0 & 0 \\
Pre-share women & 31 & 11.91 & 9.41 & 0 & 33 \\
Change in share women & 28 & 7.82 & 5.13 & 2 & 28
\end{tabular}

Note: The first column presents the number of observations, the second presents the mean value, the third presents the standard deviation, and the fourth and fifth columns present the minimum and maximum value respectively.

Source: Muessig Verlag (2016): Die Großen 500. 
Table 9: Effect of the gender quota on economic performance at the time of the announcement.

\begin{tabular}{|c|c|c|c|c|c|c|c|c|}
\hline \multirow{2}{*}{ Private firms full co-determination } & \multirow{2}{*}{$\begin{array}{c}\text { Supervisory board } \\
\text { (1) } \\
\text { Share women }\end{array}$} & \multirow{2}{*}{$\begin{array}{c}\text { Management board } \\
(2) \\
\text { Share women }\end{array}$} & \multicolumn{6}{|c|}{ Financial variables } \\
\hline & & & $\begin{array}{c}(3) \\
\log \text { EBITDA }\end{array}$ & $\begin{array}{c}(4) \\
\text { ROA }\end{array}$ & $\begin{array}{c}(5) \\
\mathrm{ROE}\end{array}$ & $\begin{array}{c}(6) \\
\text { Firm size }\end{array}$ & $\begin{array}{c}(7) \\
\text { Log employment }\end{array}$ & $\begin{array}{c}(8) \\
\text { Log wages }\end{array}$ \\
\hline Diff-in-Diff & $\begin{array}{c}4.333^{* * *} \\
(0.461)\end{array}$ & $\begin{array}{l}-0.356 \\
(0.563)\end{array}$ & $\begin{array}{c}0.142^{*} \\
(0.0624)\end{array}$ & $\begin{array}{c}0.231 \\
(0.734)\end{array}$ & $\begin{array}{l}-6.317 \\
(3.356)\end{array}$ & $\begin{array}{c}0.0281 \\
(0.0245)\end{array}$ & $\begin{array}{c}0.0113 \\
(0.0207)\end{array}$ & $\begin{array}{l}-0.395^{*} \\
(0.153)\end{array}$ \\
\hline Time FE & Yes & Yes & Yes & Yes & Yes & Yes & Yes & Yes \\
\hline Firm FE & Yes & Yes & Yes & Yes & Yes & Yes & Yes & Yes \\
\hline Observations & 3563 & 4211 & 1223 & 934 & 934 & 1979 & 3901 & 862 \\
\hline R-squared & 0.77 & 0.57 & 0.92 & 0.46 & 0.24 & 0.98 & 0.96 & 0.62 \\
\hline F-statistic & 68.69 & 12.94 & 7.66 & 4.15 & 2.56 & 20.09 & 10.21 & 2.58 \\
\hline Public firms $1 / 3$ representation & $\begin{array}{c}(1) \\
\text { Share women }\end{array}$ & $\begin{array}{c}(2) \\
\text { Share women }\end{array}$ & $\begin{array}{c}(3) \\
\text { Log EBITDA }\end{array}$ & $\begin{array}{c}(4) \\
\text { ROA }\end{array}$ & $\begin{array}{c}(5) \\
\text { ROE }\end{array}$ & $\begin{array}{c}(6) \\
\text { Firm size }\end{array}$ & $\begin{array}{c}(7) \\
\text { Log employment }\end{array}$ & $\begin{array}{c}(8) \\
\log \text { wages }\end{array}$ \\
\hline Diff-in-Diff & $\begin{array}{l}5.093^{* * *} \\
(0.796)\end{array}$ & $\begin{array}{c}0.268 \\
(0.906)\end{array}$ & $\begin{array}{l}0.294^{* * *} \\
(0.0876)\end{array}$ & $\begin{array}{l}-0.812 \\
(0.832)\end{array}$ & $\begin{array}{l}-14.02^{*} \\
(7.126)\end{array}$ & $\begin{array}{l}0.208^{* * *} \\
(0.0419)\end{array}$ & $\begin{array}{c}0.116^{*} \\
(0.0470)\end{array}$ & $\begin{array}{l}-0.0735 \\
(0.182)\end{array}$ \\
\hline Time FE & Yes & Yes & Yes & Yes & Yes & Yes & Yes & Yes \\
\hline Firm FE & Yes & Yes & Yes & Yes & Yes & Yes & Yes & Yes \\
\hline Observations & 1106 & 1118 & 805 & 669 & 668 & 936 & 1205 & 574 \\
\hline R-squared & 0.76 & 0.63 & 0.95 & 0.66 & 0.50 & 0.99 & 0.97 & 0.56 \\
\hline F-statistic & 49.18 & 6.65 & 8.19 & 4.57 & 2.77 & 15.90 & 2.17 & 2.53 \\
\hline
\end{tabular}

Note: The independent variable is the share of female members over the total members of the respective board in columns (1) and (2) and the following financial variables: log of earnings before interest, taxes, depreciation and amortization in column (3), return on assets in column (4), return on equity in column (5), log of firm assets in column (6), log of the number of employees in column (7) and log of wages and salaries in column (8). The treatment year is 2013. Affected firms are those that satisfied the requirements of the quota law when it was passed: being listed and subject to parity co-determination under the Co-determination Act. Robust standard errors in parentheses. Significance ${ }^{*} p<0.1,{ }^{* *} p<0.05,{ }^{* * *} p<0.01$ Source: Muessig Verlag (2016): Die Großen 500, Datastream and Compustat Global. 
Table 10: Effect of the gender quota on economic performance at the time of the implementation.

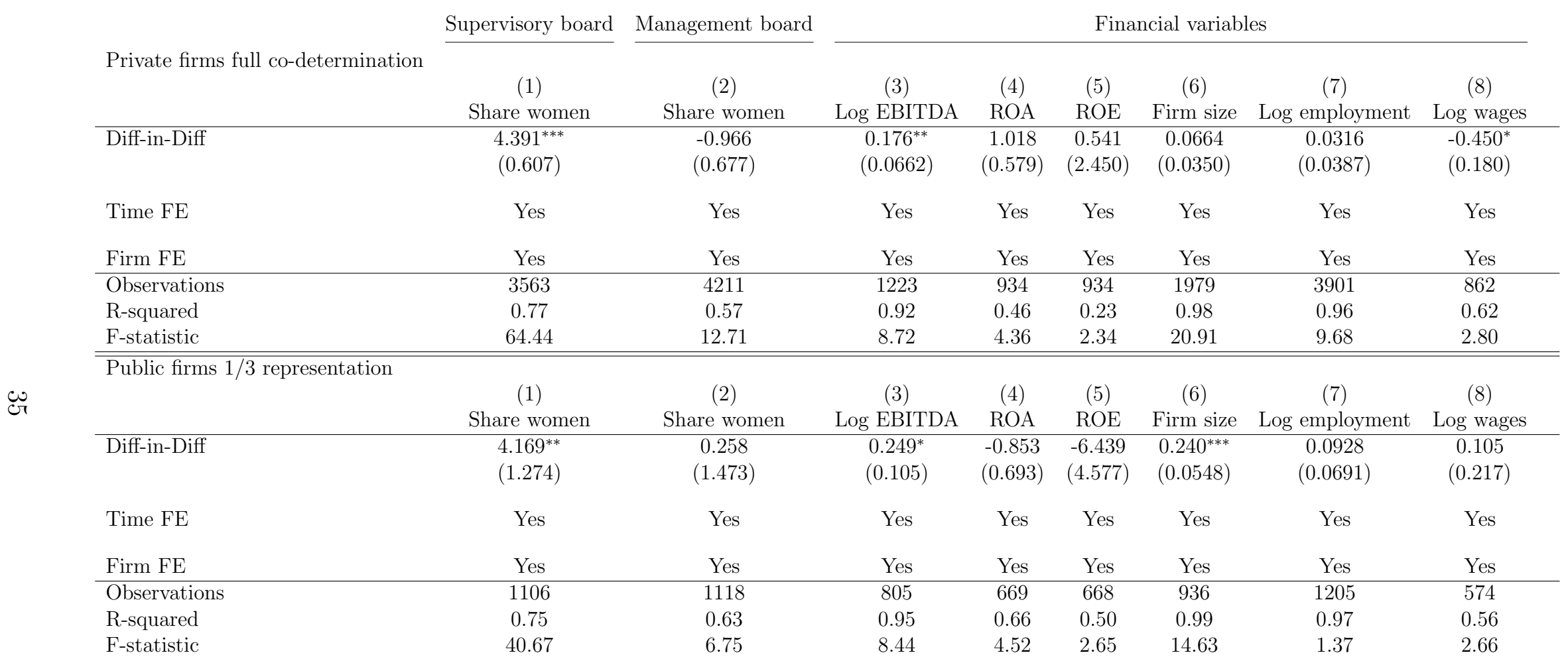

Note: The independent variable is the share of female members over the total members of the respective board in columns (1) and (2) and the following financial variables: log of earnings before interest, taxes, depreciation and amortization in column (3), return on assets in column (4), return on equity in column (5), log of firm assets in column (6), log of the number of employees in column (7) and log of wages and salaries in column (8). The treatment year is 2015. Eligible firms are those that satisfied the requirements of the quota law when it was passed: being listed and subject to parity co-determination under the Co-determination Act. Robust standard errors in parentheses. Significance ${ }^{*} p<0.1,{ }^{* *} p<0.05,{ }^{* * *} p<0.01$ Source: Muessig Verlag (2016): Die Großen 500, Datastream and Compustat Global. 
Table 11: Intensive margin of the effect of the gender quota in eligible firms.

\begin{tabular}{|c|c|c|c|c|c|c|c|c|}
\hline & Supervisory board & Management board & \multicolumn{6}{|c|}{ Financial variables } \\
\hline & $\begin{array}{c}(1) \\
\text { Number females }\end{array}$ & $\begin{array}{c}(2) \\
\text { Number females }\end{array}$ & $\begin{array}{c}(3) \\
\text { Log EBITDA }\end{array}$ & $\begin{array}{c}(4) \\
\mathrm{ROA}\end{array}$ & $\begin{array}{c}(5) \\
\mathrm{ROE}\end{array}$ & $\begin{array}{c}(6) \\
\text { Firm size }\end{array}$ & $\begin{array}{c}(7) \\
\text { Log employment }\end{array}$ & $\begin{array}{c}(8) \\
\text { Log wages }\end{array}$ \\
\hline Time dummy & $\begin{array}{c}1.631^{* * *} \\
(0.299)\end{array}$ & $\begin{array}{c}0.157 \\
(0.0829)\end{array}$ & $\begin{array}{c}0.418^{*} \\
(0.208)\end{array}$ & $\begin{array}{c}0.943 \\
(1.039)\end{array}$ & $\begin{array}{l}1.147 \\
(2.874)\end{array}$ & $\begin{array}{c}0.298 \\
(0.216)\end{array}$ & $\begin{array}{l}0.0656 \\
(0.130)\end{array}$ & $\begin{array}{l}-0.575 \\
(0.365)\end{array}$ \\
\hline Middle intensity & $\begin{array}{l}0.0658 \\
(0.268)\end{array}$ & $\begin{array}{c}0.0399 \\
(0.0759)\end{array}$ & $\begin{array}{l}-0.240 \\
(0.212)\end{array}$ & $\begin{array}{l}-0.259 \\
(1.321)\end{array}$ & $\begin{array}{l}-0.381 \\
(3.398)\end{array}$ & $\begin{array}{l}-0.123 \\
(0.235)\end{array}$ & $\begin{array}{l}-0.0115 \\
(0.0693)\end{array}$ & $\begin{array}{l}0.0119 \\
(0.309)\end{array}$ \\
\hline Time FE & Yes & Yes & Yes & Yes & Yes & Yes & Yes & Yes \\
\hline Observations & 596 & 604 & 656 & 531 & 531 & 683 & 708 & 508 \\
\hline R-squared & 0.21 & 0.10 & 0.54 & 0.08 & 0.08 & 0.55 & 0.72 & 0.04 \\
\hline F-statistic & 15.69 & 5.02 & 63.82 & 2.65 & 2.50 & 77.14 & 156.81 & 1.72 \\
\hline
\end{tabular}

Note: The independent variable is the share of female members over the total members of the respective board in columns (1) and (2) and the following financial variables: $\log$ of earnings before interest, taxes, depreciation and amortization in column (3), return on assets in column (4), return on equity in column (5), log of firm assets in column (6), log of the number of employees in column (7) and log of wages and salaries in column (8). The treatment year is 2013. Intensity of the treatment is measured as the size of the board mandated by law and it has three categories. Low intensity is the omitted category. Robust standard errors in parentheses. Significance ${ }^{*} p<0.1,{ }^{* *} p<0.05,{ }^{* * *} p<0.01$ Source: Muessig Verlag (2016): Die Großen 500, Datastream and Compustat Global. 
Table 12: Effect of the gender quota on board composition and log EBITDA by the pre-reform share of women on supervisory board at the regional level

First quantile

\begin{tabular}{|c|c|c|c|c|c|c|c|c|c|c|}
\hline & \multicolumn{2}{|c|}{ Supervisory board } & \multicolumn{2}{|c|}{ Management board } & \multirow{2}{*}{$\begin{array}{c}\text { Financial variables } \\
(5) \\
\text { Log EBITDA }\end{array}$} & \multicolumn{2}{|c|}{ Supervisory board } & \multicolumn{2}{|c|}{ Management board } & \multirow{2}{*}{$\begin{array}{c}\text { Financial variables } \\
(10) \\
\text { Log EBITDA }\end{array}$} \\
\hline & $\begin{array}{c}(1) \\
\text { Share women }\end{array}$ & $\begin{array}{c}\text { (2) } \\
\text { Number women }\end{array}$ & $\begin{array}{c}\text { (3) } \\
\text { Share women }\end{array}$ & $\begin{array}{c}\text { (4) } \\
\text { Number women }\end{array}$ & & $\begin{array}{c}(6) \\
\text { Share women }\end{array}$ & $\begin{array}{c}(7) \\
\text { Number women }\end{array}$ & $\begin{array}{c}\text { (8) } \\
\text { Share women }\end{array}$ & $\begin{array}{c}\text { (9) } \\
\text { Number women }\end{array}$ & \\
\hline Diff-in-Diff & $\begin{array}{c}6.251^{* * *} \\
(0.735)\end{array}$ & $\begin{array}{c}1.005^{* * *} \\
(0.129)\end{array}$ & $\begin{array}{l}3.160^{* *} \\
(1.192)\end{array}$ & $\begin{array}{c}0.133^{*} \\
(0.0570)\end{array}$ & $\begin{array}{c}0.0929 \\
(0.0905)\end{array}$ & $\begin{array}{c}4.901^{* * *} \\
(0.934)\end{array}$ & $\begin{array}{c}0.662^{* * *} \\
(0.143)\end{array}$ & $\begin{array}{c}0.637 \\
(0.990)\end{array}$ & $\begin{array}{l}0.0982^{*} \\
(0.0496)\end{array}$ & $\begin{array}{l}-0.0504 \\
(0.0972)\end{array}$ \\
\hline
\end{tabular}

\begin{tabular}{|c|c|c|c|c|c|c|c|c|c|c|}
\hline Time FE & Yes & Yes & Yes & Yes & Yes & Yes & Yes & Yes & Yes & Yes \\
\hline Firm FE & Yes & Yes & Yes & Yes & Yes & Yes & Yes & Yes & Yes & Yes \\
\hline Observations & 2155 & 1368 & 2623 & 2514 & 409 & 1328 & 902 & 1585 & 1512 & 356 \\
\hline R-squared & 0.80 & 0.83 & 0.59 & 0.61 & 0.94 & 0.78 & 0.78 & 0.61 & 0.65 & 0.94 \\
\hline F-statistic & 25.82 & 20.60 & 5.56 & 6.53 & 2.11 & 18.98 & 16.78 & 6.15 & 6.40 & 4.91 \\
\hline
\end{tabular}

\begin{tabular}{|c|c|c|c|c|c|c|c|c|c|c|}
\hline & \multicolumn{2}{|c|}{ Supervisory board } & \multicolumn{2}{|c|}{ Management board } & \multirow{2}{*}{$\begin{array}{c}\text { Financial variables } \\
(5) \\
\text { Log EBITDA }\end{array}$} & \multicolumn{2}{|c|}{ Supervisory board } & \multicolumn{2}{|c|}{ Management board } & \multirow{2}{*}{$\begin{array}{c}\frac{\text { Financial variables }}{(10)} \\
\text { Log EBITDA }\end{array}$} \\
\hline & $\begin{array}{c}(1) \\
\text { Share women }\end{array}$ & $\begin{array}{c}(2) \\
\text { Number women }\end{array}$ & $\begin{array}{c}(3) \\
\text { Share women }\end{array}$ & $\begin{array}{c}(4) \\
\text { Number women }\end{array}$ & & $\begin{array}{c}(6) \\
\text { Share women }\end{array}$ & $\begin{array}{c}(7) \\
\text { Number women }\end{array}$ & $\begin{array}{c}\text { (8) } \\
\text { Share women }\end{array}$ & $\begin{array}{c}\text { (9) } \\
\text { Number women }\end{array}$ & \\
\hline Diff-in-Diff & $\begin{array}{c}3.353^{* * *} \\
(0.994)\end{array}$ & $\begin{array}{l}0.437^{* *} \\
(0.150)\end{array}$ & $\begin{array}{c}-4.494^{* * *} \\
(0.964)\end{array}$ & $\begin{array}{c}-0.183^{* * *} \\
(0.0463)\end{array}$ & $\begin{array}{l}0.0518 \\
(0.127)\end{array}$ & $\begin{array}{c}4.344^{* * *} \\
(0.832)\end{array}$ & $\begin{array}{c}0.394^{* * *} \\
(0.116)\end{array}$ & $\begin{array}{l}-1.371^{*} \\
(0.655)\end{array}$ & $\begin{array}{l}-0.0124 \\
(0.0448)\end{array}$ & $\begin{array}{c}0.476^{* * *} \\
(0.118)\end{array}$ \\
\hline Time FE & Yes & Yes & Yes & Yes & Yes & Yes & Yes & Yes & Yes & Yes \\
\hline Firm FE & Yes & Yes & Yes & Yes & Yes & Yes & Yes & Yes & Yes & Yes \\
\hline Observations & 1372 & 990 & 1654 & 1562 & 289 & 1886 & 1299 & 2324 & 2159 & 496 \\
\hline R-squared & 0.77 & 0.80 & 0.60 & 0.69 & 0.92 & 0.79 & 0.81 & 0.63 & 0.64 & 0.91 \\
\hline F-statistic & 15.89 & 13.83 & 5.62 & 6.44 & 2.61 & 25.83 & 28.32 & 3.61 & 2.21 & 5.79 \\
\hline
\end{tabular}

Note: The independent variable is the share of female members over the total members of the supervisory board in column (1), the number of female members of the supervisory board in column (2), and the same for the management board in columns (3) and (4). The sample is divided by the quantiles of the regional share of women in 2012. The treatment year is 2013. Eligible firms are those that satisfied the requirements of the quota law: being listed and subject to parity co-determination under the Co-determination Act. Robust standard errors in parentheses. Significance $* p<0.1$, ** $p<0.05,{ }^{* * *} p<0.01$

Source: Muessig Verlag (2016): Die Großen 500, Datastream and Compustat Global. 


\section{A Placebo treatment group}

\begin{tabular}{|c|c|c|c|}
\hline & Super & isory board & Management board \\
\hline & All sample & Non-financial firms & All sample \\
\hline & (1) & $(2)$ & $(3)$ \\
\hline & Share women & Share women & Share women \\
\hline Time dummy & $6.085^{* * *}$ & $5.282^{* * *}$ & $3.820^{* * *}$ \\
\hline & $(0.441)$ & $(0.468)$ & $(0.536)$ \\
\hline Placebo Affected & 0.0827 & 0.0668 & 0.295 \\
\hline & $(0.171)$ & $(0.170)$ & $(0.225)$ \\
\hline Time dummy $\times$ Placebo Affected & -0.0726 & 0.214 & -0.321 \\
\hline & $(0.323)$ & $(0.338)$ & $(0.392)$ \\
\hline Time FE & Yes & Yes & Yes \\
\hline Firm FE & Yes & Yes & Yes \\
\hline Observations & 6283 & 5040 & 7639 \\
\hline R-squared & 0.78 & 0.80 & 0.61 \\
\hline F-statistic & 46.67 & 35.89 & 14.63 \\
\hline
\end{tabular}

Note: The independent variable is the share of female members over the total members of the supervisory board in column (1) and (2), with the management board in column (3). The treatment year is 2013. Placebo affected is a dummy that takes value 1 for a randomly selected subset of firms and 0 for the rest. Robust standard errors in parentheses. Significance ${ }^{*} p<0.1,{ }^{* *} p<0.05,{ }^{* * *} p<0.01$.

Source: Muessig Verlag (2016): Die Großen 500. 


\section{B Difference-in-difference with regional time trends}

Table 13: Effect of the introduction of the gender quota on the share of women on the supervisory board with regional time trends.

\begin{tabular}{|c|c|c|c|c|}
\hline & \multicolumn{4}{|c|}{ Supervisory board } \\
\hline & \multicolumn{2}{|c|}{ All sample } & \multirow{3}{*}{$\begin{array}{c}\frac{\text { Non-financial firms }}{(3)} \\
\text { Share women }\end{array}$} & \multirow{3}{*}{$\begin{array}{c}\text { Firms West Germany } \\
(4) \\
\text { Share women }\end{array}$} \\
\hline & $(1)$ & $(2)$ & & \\
\hline & Share women & Average share & & \\
\hline Time dummy & $\begin{array}{c}6.048^{* * *} \\
(0.961)\end{array}$ & $\begin{array}{c}3.226^{* * *} \\
(0.479)\end{array}$ & $\begin{array}{c}5.221^{* * *} \\
(0.992)\end{array}$ & $\begin{array}{c}6.041^{* * *} \\
(0.958)\end{array}$ \\
\hline Eligible & $\begin{array}{l}6.730^{* *} \\
(2.235)\end{array}$ & $\begin{array}{c}1.720 \\
(0.976)\end{array}$ & $\begin{array}{l}7.030^{* *} \\
(2.255)\end{array}$ & $\begin{array}{l}6.710^{* *} \\
(2.229)\end{array}$ \\
\hline Time dummy X Eligible & $\begin{array}{c}5.301^{* * *} \\
(0.455)\end{array}$ & $\begin{array}{c}5.294^{* * *} \\
(0.303)\end{array}$ & $\begin{array}{c}5.643^{* * *} \\
(0.465)\end{array}$ & $\begin{array}{c}5.345^{* * *} \\
(0.457)\end{array}$ \\
\hline Time FE & Yes & Yes & Yes & Yes \\
\hline Firm FE & Yes & Yes & Yes & Yes \\
\hline Region X Time FE & Yes & Yes & Yes & Yes \\
\hline Observations & 6250 & 6383 & 5012 & 5849 \\
\hline R-squared & 0.79 & 0.89 & 0.81 & 0.79 \\
\hline F-statistic & 7.01 & 13.14 & 5.91 & 8.80 \\
\hline
\end{tabular}

Note: The independent variable is the share of female members over the total members of the supervisory board in column (1), (3), and (4), with the average share of females in all periods before and after the reform in column (2). The treatment year is 2013. Eligible firms are those that satisfied the requirements of the quota law: being listed and subject to parity co-determination under the Co-determination Act. Robust standard errors in parentheses. Significance ${ }^{*} p<0.1,{ }^{* *} p<0.05,{ }^{* * *} p<0.01$ Source: Muessig Verlag (2016): Die Großen 500. 


\section{Variables descriptive statistics in matched and un- matched samples}

\begin{tabular}{|c|c|c|c|c|c|c|}
\hline Variable & (Un)Matched & $\begin{array}{l}\text { Mean } \\
\text { treated }\end{array}$ & $\begin{array}{l}\text { Mean } \\
\text { control }\end{array}$ & \%bias & $\%$ reduct bias & $\mathrm{V}(\mathrm{T}) / \mathrm{V}(\mathrm{C})$ \\
\hline \multirow[t]{2}{*}{ D.share } & $\mathrm{U}$ & 23.484 & 13.608 & 16.6 & & 1.14 \\
\hline & M & 23.484 & 19.161 & 7.3 & 56.2 & $1.39^{*}$ \\
\hline \multirow[t]{2}{*}{ D.logEBITDA } & $\mathrm{U}$ & .03342 & .01556 & 5.0 & & $0.23 *$ \\
\hline & M & .03342 & .06026 & -7.4 & -50.3 & $0.20^{*}$ \\
\hline \multirow[t]{2}{*}{ D2.logEBITDA } & $\mathrm{U}$ & -.00381 & -.01913 & 2.5 & & $0.29 *$ \\
\hline & M & -.00381 & -.03418 & 5.0 & -98.3 & $0.12^{*}$ \\
\hline \multirow[t]{2}{*}{ D3.logEBITDA } & $\mathrm{U}$ & -.00743 & .13507 & -12.8 & & $0.35 *$ \\
\hline & M & -.00743 & -.15852 & 13.6 & -6.0 & $0.12^{*}$ \\
\hline \multirow[t]{2}{*}{ D4.logEBITDA } & $\mathrm{U}$ & -.13062 & .55201 & -29.7 & & $0.33^{*}$ \\
\hline & M & -.13062 & -.45993 & 14.3 & 51.8 & $0.18^{*}$ \\
\hline \multirow[t]{2}{*}{ D.ROA } & $\mathrm{U}$ & -.2037 & -.30068 & 2.1 & & $0.09^{*}$ \\
\hline & M & -.2037 & -.42881 & 5.0 & -132.1 & $0.30^{*}$ \\
\hline \multirow[t]{2}{*}{ D2.ROA } & $\mathrm{U}$ & -.04529 & -.12238 & 1.0 & & $0.07^{*}$ \\
\hline & M & -.04529 & -.29451 & 3.1 & -223.3 & $0.11^{*}$ \\
\hline \multirow[t]{2}{*}{ D3.ROA } & $\mathrm{U}$ & .08478 & 15.041 & -9.3 & & $0.07^{*}$ \\
\hline & M & .08478 & -11.243 & 7.9 & 14.8 & $0.06^{*}$ \\
\hline \multirow[t]{2}{*}{ D4.ROA } & $\mathrm{U}$ & -.55821 & 52.312 & -19.5 & & $0.08^{*}$ \\
\hline & M & -.55821 & -47.593 & 14.2 & 27.4 & $0.05^{*}$ \\
\hline \multirow[t]{2}{*}{ D.ROE } & $\mathrm{U}$ & -.74053 & -10.391 & 3.0 & & $0.16^{*}$ \\
\hline & M & -.74053 & -.28001 & -4.6 & -54.3 & $0.30^{*}$ \\
\hline \multirow[t]{2}{*}{ D2.ROE } & $\mathrm{U}$ & .32894 & -.68938 & 6.1 & & $0.14^{*}$ \\
\hline & M & .32894 & 14.871 & -6.9 & -13.7 & $0.18^{*}$ \\
\hline \multirow[t]{2}{*}{ D3.ROE } & $\mathrm{U}$ & .92018 & 28.503 & -6.2 & & $0.15^{*}$ \\
\hline & M & .92018 & 10.429 & -0.4 & 93.6 & $0.14^{*}$ \\
\hline \multirow[t]{2}{*}{ D4.ROE } & $\mathrm{U}$ & -.82881 & 10.903 & -19.6 & & $0.16^{*}$ \\
\hline & M & -.82881 & -49.188 & 6.8 & 65.1 & $0.13^{*}$ \\
\hline \multirow[t]{2}{*}{ D.size } & $\mathrm{U}$ & .05911 & .03974 & 12.0 & & $0.33^{*}$ \\
\hline & M & .05911 & .0835 & -15.1 & -25.9 & $0.33^{*}$ \\
\hline \multirow[t]{2}{*}{ D2.size } & $\mathrm{U}$ & .00148 & -.02354 & 12.4 & & $0.47^{*}$ \\
\hline & M & .00148 & .02016 & -9.3 & 25.3 & $0.63^{*}$ \\
\hline \multirow[t]{2}{*}{ D3.size } & $\mathrm{U}$ & .00155 & -.02907 & 9.7 & & $0.57^{*}$ \\
\hline & M & .00155 & .01156 & -3.2 & 67.3 & 0.91 \\
\hline \multirow[t]{2}{*}{ D4.size } & $\mathrm{U}$ & .00115 & .01328 & -2.2 & & $0.58^{*}$ \\
\hline & M & .00115 & -.02752 & 5.1 & -136.5 & $0.68^{*}$ \\
\hline \multirow[t]{2}{*}{ D.logemploy } & $\mathrm{U}$ & .02572 & .02144 & 0.7 & & $0.01^{*}$ \\
\hline & M & .02572 & .04762 & -3.8 & -411.3 & $0.35^{*}$ \\
\hline \multirow[t]{2}{*}{ D2.logemploy } & $\mathrm{U}$ & -.04849 & .01812 & -6.8 & & $0.20^{*}$ \\
\hline & M & -.04849 & -.00982 & -3.9 & 41.9 & $12.99^{*}$ \\
\hline D3.logemploy & $\mathrm{U}$ & -.08656 & .0554 & -8.0 & & 0.96 \\
\hline
\end{tabular}




$\begin{array}{lllllll} & \mathrm{M} & -.08656 & -.01654 & -3.9 & 50.7 & 42.96^{*} \\ \text { D4.logemploy } & \mathrm{U} & -.11954 & .11424 & -7.0 & & 2.90^{*} \\ & \mathrm{M} & -.11954 & -.04602 & -2.2 & 68.6 & 62.37^{*} \\ \text { D.logwages } & \mathrm{U} & .0132 & -.03584 & 5.1 & & 0.45^{*} \\ & \mathrm{M} & .0132 & .01224 & 0.1 & 98.0 & 0.62^{*} \\ \text { D2.logwages } & \mathrm{U} & .07121 & .10228 & -1.9 & & 0.51^{*} \\ & \mathrm{M} & .07121 & .13918 & -4.2 & -118.8 & 0.62^{*} \\ \text { D3.logwages } & \mathrm{U} & .01578 & .1914 & -6.0 & & 0.77 \\ & \mathrm{M} & .01578 & .25441 & -8.1 & -35.9 & 0.88 \\ \text { D4.logwages } & \mathrm{U} & .00558 & .25502 & -4.7 & & 1.25 \\ & \mathrm{M} & .00558 & .64025 & -11.9 & -154.4 & 1.29\end{array}$

Note: ${ }^{*}$ if variance ratio outside $[0.82 ; 1.23]$ for Unmatched and $[0.73 ; 1.37]$ for Matched.

Source: Muessig Verlag (2016): Die Großen 500, Datastream and Compustat Global. 


\section{Propensity score matching}

\begin{tabular}{|c|c|c|c|c|c|c|c|c|c|}
\hline & \multirow{2}{*}{$\frac{\text { Supervisory board }}{(1)}$} & \multirow{2}{*}{$\frac{\text { Management board }}{(2)}$} & \multicolumn{7}{|c|}{ Financial variables } \\
\hline & & & $\begin{array}{c}(3) \\
\text { Log EBITDA }\end{array}$ & $\begin{array}{c}(4) \\
B O A\end{array}$ & $\begin{array}{c}(5) \\
B O F\end{array}$ & $\begin{array}{l}(6) \\
\text { Firm size }\end{array}$ & $\begin{array}{c}(7) \\
\end{array}$ & $\begin{array}{c}(8) \\
\text { Log staff cost }\end{array}$ & $\begin{array}{c}(9) \\
\text { Log wages }\end{array}$ \\
\hline Diff-in-diff & $\begin{array}{c}8.246^{* * *} \\
(2.260)\end{array}$ & $\begin{array}{c}1.503 \\
(2.128)\end{array}$ & $\begin{array}{c}0.623^{* * *} \\
(0.226)\end{array}$ & $\begin{array}{c}0.549 \\
(0.812)\end{array}$ & $\begin{array}{l}0.0542 \\
(1.516)\end{array}$ & $\begin{array}{c}0.550^{* *} \\
(0.273)\end{array}$ & $\begin{array}{c}0.606^{* * *} \\
(0.224)\end{array}$ & $\begin{array}{c}0.107 \\
(0.296)\end{array}$ & \\
\hline Observations & 317 & 317 & 385 & 385 & 385 & 385 & 385 & 385 & \\
\hline
\end{tabular}

Note: The independent variable is the share of female members over the total members of the respective board in columns (1) and (2) and the following financial variables: log of earnings before interest, taxes, depreciation and amortization in column (3), return on assets in column (4), return on equity in column (5), log of firm assets in column (6), log of the number of employees in column (7) and log of wages and salaries in column (8). The treatment year is 2013. Eligible firms are those that satisfied the requirements of the quota law when it was passed: being listed and subject to parity co-determination under the Co-determination Act. The control group has been matched using propensity scores. Robust standard errors in parentheses. Significance ${ }^{*} p<0.1,{ }^{* *} p<0.05,{ }^{* * *} p<0.01$

Source: Muessig Verlag (2016): Die Großen 500, Datastream and Compustat Global. 